\title{
Responsabilidade do estado em face dos danos ambientais: Um olhar sobre o Caso da SAMARCO
}

\author{
Josiane de Oliveira Lopes $^{1}$; Liliane Caraciolo Ferreira ${ }^{2}$
}

\begin{abstract}
Resumo: No presente estudo será realizada uma breve análise dos conceitos de ordem jurídica na perspectiva da legislação brasileira referente à responsabilidade do Estado em face dos danos ambientais, direcionado ao evento do rompimento da barragem da empresa Samarco, ocorrido em Minas Gerais em novembro de 2015. Uma vez que a necessidade de preservar e proteger o meio ambiente são premissas básicas na obtenção de uma qualidade de vida satisfatória. E na satisfação desta necessidade, a norma jurídica deve ser o elemento norteador na atuação dos grupos de proteção ambiental, cidadãos, entidades sociais e principalmente na atuação do Estado.
\end{abstract}

Palavras-Chave: Responsabilidade do Estado. Dano ambiental. Samarco.

\section{State Responsibility in face of Environmental Damage: A look at the case of SAMARCO}

\begin{abstract}
This study will be conducted a brief analysis of the legal concepts in the context of Brazilian legislation on the state's responsibility in the face of environmental damage, directed to the dam break event Samarco company, occurred in Minas Gerais inNovember 2015. Once the need to preserve and protect the environment are basic premises in obtaining a satisfactory quality of life. Andin meeting this need, the rule of law must be the guiding element in the performance of environmental protection groups, citizens, social organizations and especially in State intervention.
\end{abstract}

Keywords: State responsibility. environmental damage. Samarco.

\section{Introdução}

Assim, com o objetivo de refletir sobre a responsabilidade do Estado pelo Dano Ambiental ocorrido com a empresa Samarco, vez que em 5 de novembro de 2015, o rompimento da barragem de responsabilidade da empresa vitimou pessoas e animais, provocando um vazamento de cerca 62 milhões de metros cúbicos de lama, de acordo com o pesquisador Marcos Freitas, coordenador executivo do Instituto Virtual Internacional de Mudanças Globais da Universidade Federal do Rio de Janeiro, lama essa que escorreu por quilômetros destruindo todo o Rio Doce, atingindo, inclusive o mar. $^{7}$

\footnotetext{
${ }^{1}$ Universidade Federal do Vale do São Francisco - UNIVASF

${ }^{2}$ Possui graduação em Economia (UFPE), mestrado em Administração Rural (UFRPE) e doutorado em Psicologia, área de Psicologia Social pela Universidade Federal do Espírito Santo (UFES). É professora da Universidade Federal do Vale do São Francisco na área de Economia desde 2004. Atualmente é Coordenadora do Programa de Pós Graduação em Gestão Pública UAB/CAPES/UNIVASF.

7 UFRJ. Revista do Instituto Virtual Internacional de Mudanças Globais, Disponível em: <<http://www.ivig.coppe.ufrj.br/index.php〉> acessado em 11 de abril de 2016.
} 
Ademais, a escolha do presente tema baseia-se na relevância jurídica e social que o tema traz à tona, principalmente porque as questões envolvendo o meio ambiente representam um importante elemento de enfrentamento que todo o gestor público deve se deparar, sobretudo com comportamentos preventivos para que sejam evitados a ocorrências de catástrofes ambientais a exemplo da ocorrida no Estado de Minas Gerais, evitando com isso os prejuízos ao meio ambiente equilibrado e também no desenvolvimento da economia local e na vida das pessoas.

Sendo a Responsabilidade do Estado em matéria ambiental, um assunto amplamente tratado pela doutrina brasileira, a autora Maria Zanella Di Pietro traz um norteamento interessante ao afirmar que "a responsabilidade do Estado não pode se reger pelos princípios do Código Civil, porque se sujeita a regras especiais" (DI PIETRO, 2007, p. 526). Nesta seara, a teoria da culpa administrativa ganha força - A referida teoria envolve os serviços que são executados de forma precárias, nesta hipótese o Estado responderia independentemente da existência de culpa do agente. Nesta mesma linha Meirelles (2005, p. 619), aborda a teoria do risco na qual se insere duas modalidades: a do risco administrativo e a do risco integral, assim a diferença inicial é que no risco administrativo as causas excludentes da responsabilidade do Estado como o caso fortuito, força maior e culpa de terceiros são considerados e, já na hipótese do risco integral, estas excludentes da responsabilidade não estão presentes. Com isso, o tema em estudo apresenta novas facetas, pois, o Direito não sendo imutável é uma construção, que a todo o momento é amoldado por indivíduos que são sujeitos de sua própria história.

Deste modo, na primeira parte deste estudo será tratado o conceito de Responsabilidade do Estado e, para tanto, será utilizada a doutrina de alguns autores da área de Direito Administrativo, a exemplo de Hely Lopes de Meirelles e Maria Sylvia Zannela Di Pietro, com o fito principal de refletir a respeito de algumas das discussões doutrinárias que versam em torno do instituto da responsabilidade na vertente administrativa.

$\mathrm{Na}$ segunda parte será tratada a temática voltada para a vertente ambiental, com isso, trazendo o entendimento de doutrinadores da área de Direito ambiental com o fito, de conceituar e caracterizar o Dano ambiental, ventilando, de forma sucinta, os conceitos trazidos pelos autores Paulo Machado (1998) e Porfírio Júnior (2002), além da esclarecedora classificação de Dano Ambiental de Edis Milaré (2001).

E ainda, na terceira parte do artigo será evidenciado evento ocorrido com a mineradora Samarco em Minas Gerais, fazendo uma reflexão sobre responsabilidade do Estado pelo dano ambiental ali ocorrido, assim, a luz dos conceitos tratados e dos princípios constitucionais e da jurisprudência compreendendo o seu papel preponderante do Estado como ente fiscalizador e a sua responsabilidade perante o dano ambiental ali ocorrido além da responsabilidade 
Id on Line Revista Multidisciplinar e de Psicologia

Id on Line Revista Multidisciplinar e de Psicologia

de manutenção do meio ambiente ecologicamente equilibrado . Como o evento ocorrido na Cidade de Mariana é recente, sem portanto posicionamento jurisprudencial a respeito, vamos demonstrar alguns julgamentos demonstrando o comportamento da jurisprudência em casos semelhantes.

\section{Responsabilidade do Estado}

O tema da responsabilidade estatal tem suscitado incertezas e controvérsias, por isso, vem inspirando estudiosos na elaboração da vasta literatura como os doutrinadores da área de Direito Administrativo Di Pietro e Hely Lopes. Isto ocorre porque, frequentemente, encontra-se equívoco presente em algumas decisões, principalmente, por ignorar os elementos que diferenciam a responsabilidade civil da responsabilidade administrativa, pois além de serem diferentes apresentam aspectos doutrinários independentes.

O alcance da expressão "Responsabilidade do Estado" é extremamente amplo, abrangendo toda a responsabilidade jurídica extracontratual de caráter não penal das pessoas jurídicas de direito público. Já a responsabilidade contratual do Estado rege-se pelos princípios dos contratos administrativos, que são a supremacia da administração pública e do interesse público.

A ideia de responsabilidade está relacionada ao conceito de obrigação, na qual surge à equivalência de contraprestação, de correspondência obrigacional de uma repercussão gerada por violação de norma ou obrigação. Toda a manifestação da atividade humana traz em si problema de responsabilidade.

Por sua vez, quando se fala em Responsabilidade do Estado está se tratando dos três tipos de funções em que se reparte o poder estatal: a administrativa, a jurisdicional e a legislativa. No entanto, utiliza-se com mais frequência a responsabilidade resultante de comportamentos da Administração Pública, visto que, em relação aos Poderes Legislativo e Judiciário essa responsabilidade incide em casos excepcionais.

Vale ressaltar que a expressão "Responsabilidade do Estado" não é de aceitação unânime pelos autores. O professor Hely Lopes Meirelles (2005), por exemplo, prefere o termo "Responsabilidade da Administração Pública", pois para este doutrinador a denominada "Responsabilidade do Estado", em regra, surge dos atos da administração e não de atos próprios do Estado como entidade política - Nesta linha ele afirma que: "Mais próprio, portanto, é falar-se em responsabilidade da Administração Pública, do que em responsabilidade do Estado, uma vez que é da atividade administrativa dos órgãos públicos e não dos atos de governo que emerge a obrigação de indenizar." 8

MEIRELLES, Hely Lopes. Direito Administrativo Brasileiro. 30 ed. São Paulo: Malheiros Editores, 2005, p 553 
Id on Line Revista Multidisciplinar e de Psicoloqia

Id on Line Revista Multidisciplinar e de Psicologia

Desta forma, o autor ainda posiciona a responsabilidade administrativa do Estado que consiste na submissão da organização estatal ao dever jurídico político de prestar informações e contas por suas ações e omissões e de corrigir as imperfeições verificadas em sua conduta.

Para Marçal Justen Filho (2006): “A Responsabilidade do Estado, numa acepção ampla, significa o dever de reconhecer a supremacia da sociedade e a natureza instrumental do aparato estatal" 9

Ao tratar do tema, Hely Lopes Meirelles de forma preliminar aponta que deveria usar o termo responsabilidade civil da Administração Pública ao invés de responsabilidade civil do Estado, pois para ele "responsabilidade civil é a que se traduz na obrigação de reparar danos patrimoniais e se exaure com a indenização" ${ }^{\text {10 }}$. Para este autor, tal teoria se baseia no risco que a atividade pública gera para os administrados e na possibilidade de acarretar danos a certos membros da comunidade. A contribuição deste doutrinador em relação ao tema vai além, principalmente, quando ele comenta sobre o $§ 6^{\circ}$ do Artigo 37 da Constituição Federal:

O parágrafo $6^{\circ}$, do art. 37 da Constituição Federal seguiu a linha traçada nas constituições anteriores, e, abandonando a privatística teoria subjetiva da culpa, orientou-se pela doutrina do Direito Público e manteve a responsabilidade objetiva da Administração, sob a modalidade do risco administrativo. Não chegou porém, aos extremos do risco integral. É o que se refere do texto constitucional e tem sido admitido pela jurisprudência. ${ }^{11}$

No entender da administrativista Maria Sylvia Di Pietro (2007) a responsabilidade extracontratual do Estado corresponde à obrigação de reparar danos causados a terceiros em decorrência de comportamentos comissivos ou omissivos, materiais ou jurídicos, lícitos ou ilícitos, imputáveis aos agentes públicos ${ }^{12}$.

\section{Teorias}

\section{Da responsabilidade Subjetiva e Objetiva}

A partir dessa noção civilista e com a progressiva afirmação da autonomia e da distinção entre o Direito Administrativo e o Direito Privado, surgem teorias publicistas sobre a responsabilidade estatal, destacando-se aquela denominada de culpa do serviço ou do acidente administrativo, que tem

\footnotetext{
9 JUSTEN FILHO, Marçal Justen. A Responsabilidade do Estado. In: FREITAS, Juarez (org.). Responsabilidade Civil do Estado. Malheiros Editores, 2006. p. 226

${ }^{10}$ MEIRELLES, 2005, p. 629.

${ }^{11}$ Ibid, p. 634.

${ }^{12}$ DI PIETRO, Maria Sylvia Zanella. Direito Administrativo. 20 ed. São Paulo: Atlas, 2007, p. 596. 
como exemplo, aquelas situações nas quais o serviço público não funciona, ou funciona mal, ou com certo atraso.

Portanto, num primeiro momento, a responsabilidade civil do Estado passou a ser admitida somente para os atos de gestão, pois seriam atos típicos do Estado, colocando com isso, o Estado e o particular em posição de igualdade. No entanto, essa teoria encontrou opositores pela dificuldade (ou impossibilidade) em dividir a personalidade do Estado, por isso, a tentativa em demarcar os atos em atos de império e atos de gestão é abandonada e com isso, surgindo a teoria da responsabilidade subjetiva.

Com a teoria da responsabilidade subjetiva ou teoria da culpa civil, o Estado torna-se responsável pelos atos de seus agentes, sendo necessário, para tanto, a existência da comprovação da culpa.

A responsabilidade com base no Direito Público surgiu com o famoso caso Blanco, conforme registro de Maria Sylvia Zanella Di Pietro (2007):

\begin{abstract}
Primeiro passo no sentido da elaboração de teorias de responsabilidade do Estado segundo princípios do direito público foi dado pela jurisprudência francesa, com o famoso caso Blanco, ocorrido em 1873: a menina Agnes Blanco, ao atravessar uma rua da cidade de Bordeaux, foi colhida por uma vagonete da Cia. Nacional de Manufatura do Fumo; seu pai promoveu ação civil de indenização, com base no princípio de que o Estado é civilmente responsável por prejuízos causados a terceiros, em decorrência de ação danosa de seus agentes. Suscitado conflito de atribuições entre a jurisdição comum e o contencioso administrativo, o Tribunal de Conflitos decidiu que a controvérsia deveria ser solucionada pelo tribunal administrativo, porque se tratava de apreciar a responsabilidade decorrente de funcionamento do serviço público. Entendeu-se que a responsabilidade do Estado não pode reger-se pelos princípios do Código Civil, porque se sujeita as regras especiais que variam conforme as necessidades do serviço e a imposição de conciliar os direitos do Estado com os direitos privados. ${ }^{13}$
\end{abstract}

Assim, a responsabilidade do Estado não poderia ser regida por princípios de Direito Civil, deste modo, surgindo a necessidade de regras fundamentadas em princípios de Direito Público.

Como defende Celso Antonio Bandeira de Mello (1999), há a responsabilidade objetiva quando há conduta comissiva do Estado em benefício do próprio Estado ou da coletividade, atingindo individualmente o particular de forma não isonômica comparativamente aos demais. Há responsabilidade subjetiva quando o dano resulta de conduta omissiva do Estado, na hipótese do serviço não funcionar, funcionar mal ou funcionar tardiamente.

Deste modo, ainda se faz necessário demonstrar a presença de culpa da Administração em relação aos fatos danosos, ficando nesta hipótese o dever de provar a ocorrência da negligência, imprudência ou imperícia, ou seja, a demonstração de que o serviço não se conduziu com a diligência média que dele se poderia legitimamente exigir.

\footnotetext{
$13 \quad$ Ibid, 2007, p.598 
Id on Line Revista Multidisciplinar e de Psicologia

Id on Line Revista Multidisciplinar e de Psicologia

No entanto, a responsabilidade do Poder Público caracteriza-se como responsabilidade de Direito Público, com fundamento nos ditames da Constituição, sem vinculação com a responsabilidade, no âmbito do Direito Civil, independentemente de atuação ou não do particular no sentido da recuperação do ambiente degradado. No entanto, não é lícita a omissão do Estado, pois, por força dos dispositivos constitucionais é ínsita à sua essência a garantia da qualidade de vida das presentes e futuras gerações.

\section{Teoria do risco}

Com base no princípio de igualdade dos ônus e encargos sociais, os benefícios ou prejuízos devem ser repartidos igualmente entre os membros da sociedade. Neste sentido, a presença da culpa é afastada, diferentemente do que ocorria na teoria da responsabilidade subjetiva e na teoria da culpa do serviço.

A teoria do risco subdivide-se em teoria do risco administrativo e teoria do risco integral. Ambas as teorias dependem da avaliação da culpa, sendo a culpa do agente ou do serviço. Desta forma, basta ao administrado demonstrar que houve um comportamento comissivo ou omisso na ocorrência do fato danoso, e também o nexo de causalidade. A diferença principal entre as duas subteorias é que a teoria do risco integral é uma modalidade extremada da teoria do risco, pois não admite nenhuma causa excludente da responsabilidade, obrigando ao Estado indenizar mesmo que o dano seja resultante da culpa ou dolo da vítima ou de força maior. A teoria do risco administrativo a Responsabilidade do Estado é afastada nos casos em que há culpa exclusiva da vítima ou força maior, sendo que, nos casos em que há culpa concorrente da vítima, o Estado indenizaria na proporção inversa do grau de culpa de vítima, ou seja, quanto maior a culpa da vítima menor será o valor devido pelo Estado, a título de indenização.

Deste modo, a teoria do risco administrativo baseia-se no princípio da igualdade dos ônus e encargos sociais, pois os beneficiários decorrentes da atuação estatal repartem-se por todos, assim como os prejuízos sofridos por alguns membros da sociedade devem ser repartidos. Quando uma pessoa sofre um ônus maior do que o suportado pelas demais, rompe-se o equilíbrio que necessariamente deve haver entre os encargos sociais. Para restabelecer esse equilíbrio, o Estado deve indenizar o prejudicado, utilizando recursos do erário. ${ }^{14}$

Maria Silvia Zanella Di Pietro (2007) adverte, contudo que:

A maior parte da doutrina não faz distinção, considerando as duas expressões - risco integral e risco administrativo - como sinônimos ou falando em risco administrativo

${ }^{14}$ DI PIETRO, 2007, p.599 
como correspondendo ao acidente administrativo. Mesmo os autores que falam em teoria do risco integral admitem as causas excludentes da responsabilidade. ${ }^{15}$

Com isso, Di Pietro (2007) ainda afirma que na teoria do risco administrativo vigora a responsabilidade objetiva, a qual dispensa o ônus da comprovação da culpa (ou dolo) do agente estatal. Tornando-se assim, o Estado responsável, inclusive patrimonialmente, pelos danos que seus servidores pratiquem estando investidos na função aos administrados.

Alguns doutrinadores não fazem distinção entre a teoria do risco integral e a teoria do risco administrativo. No entanto, esse não é o entendimento de Hely Lopes Meirelles (2005), que entende haver uma divergência entre as referidas teorias, uma vez que, para ele, a teoria do risco integral não admite excludente de responsabilidade do Estado, ao passo que aquela admite.

Com ideia semelhante o autor Inácio de Carvalho Neto (2000), que também aponta a diferença entre a teoria do risco integral e a do risco administrativo, ele afirma:

O que distingue ambas as teorias é justamente que, na do risco integral, o Estado é obrigado a indenizar, ainda que a vítima tenha agido com culpa exclusiva. Ou seja, a culpa exclusiva da vítima ou de terceiro não afasta o nexo de causalidade entre a ação ou omissão do agente e o resultado, não dispensando o Estado de indenizar a vítima. Para a teoria do risco integral, nem mesmo o caso fortuito e a força maior excluem a obrigação do Estado de indenizar. ${ }^{16}$

Nesta mesma linha de raciocínio, Diógenes Gasparini (2003) assevera: na teoria do risco integral não se discute se a vítima teve ou não culpa, porquanto o que importa é o dano por ela sofrido, o que obriga o Estado a indenizar todo e qualquer dano, desde que, envolvido no respectivo evento. Não sendo necessário o questionamento a respeito da culpa da vítima na produção do evento danoso, nem se permite qualquer prova que possa elidir essa responsabilidade. Mas, para tanto o Estado deve estar envolvido no evento. ${ }^{17}$

Nesta linha, o Poder Público tem o dever de buscar a prevenção para cumprir o seu papel sendo, portanto, prudente e cuidadoso. Se porventura houver prejuízo para as pessoas, para a propriedade ou para os recursos naturais, o Poder Público deverá responder solidariamente com o particular que causar prejuízo.

A teoria do risco foi acolhida no Brasil desde a Constituição Federal de 1946, sendo mantida na atual Constituição Federal em seu artigo 37, parágrafo $6^{\circ}$ :

Art. 37, § $6^{\circ}$ : As pessoas jurídicas de direito público e as de direito privado prestadoras de serviços públicos responderão pelos danos que seus agentes, nessa qualidade, causarem a terceiros, assegurado o direito de regresso contra o responsável nos casos de dolo ou culpa.

15 Ibid, p. 600

${ }^{16}$ CARVALHO NETO, Inácio de. Responsabilidade do Estado por ato de seus agentes. São Paulo: Atlas, 2000. p 117

17 GASPARINI, Diógenes. Direito Administrativo. $8^{\circ}$ ed, São Paulo: Saraiva, 2003. p 231. 
Ademais, desde que haja simples relação de causalidade entre o comportamento comissivo ou omissivo do Estado, já pode ser verificada a presença da responsabilidade de acordo com esta teoria. Neste caso, a responsabilidade objetiva ocorre quando o Estado, com uma ação lícita ou ilícita, cause dano a outro que teoricamente deveria estar protegido.

\section{O Dano Ambiental}

\section{Conceito de Dano Ambiental}

O constitucionalista José Afonso da Silva (2003) conceitua dano ecológico como sendo "qualquer lesão ao meio ambiente causada por condutas ou atividades de pessoa física ou jurídica de Direito Público ou de Direito Privado."18

Já o doutrinador Edis Milaré (2001), afirma que "no sistema jurídico nacional podemos identificar uma bifurcação do dano ambiental: num lado, o dano público pelo meio ambiente, que é "bem de uso comum do povo", como previsto no Art. 225 da Constituição Federal, de natureza difusa, atingindo um número indefinido de pessoas, sempre devendo ser cobrado por Ação Civil Pública ou Ação Popular e sendo a indenização destinada a um fundo; no outro lado, o dano ambiental privado, que dá ensejo à indenização dirigida à recomposição do patrimônio individual das vítimas" 19

Nesta seara é importante demonstrar o conceito de poluição prevista no artigo $3^{\circ}$, III, da Lei n ${ }^{\circ}$ 6.938 de 31 de agosto de 1981, lei essa que dispõe sobre a Política Nacional do Meio Ambiente, como:

Poluição, a degradação da qualidade ambiental resultante de atividades que direta ou indiretamente: prejudiquem a saúde, a segurança e o bem-estar da população; criem condições adversas às atividades sociais e econômicas; afetem desfavoravelmente a biota; afetem as condições estéticas ou sanitárias do meio ambiente; lancem matérias ou energia em desacordo com os padrões ambientais estabelecidos.

Podemos afirmar que, onde existir poluição no sentido do art. $3^{\circ}$, III, da Lei 6938/81, muitas vezes, haverá também o dano ambiental de acordo com o artigo $1^{\circ}$, inciso I, da Lei 7.347 de 24 de julho de 1985, visto que a definição do conceito de dano na lei processual se rege pelas normas de direito ambiental material. Portanto, nem toda a alteração negativa do meio ambiente pode ser qualificada como poluição ou dano. Com isso, o conceito e o conteúdo do dano ambiental não encontram na legislação respaldo suficiente.

18 SILVA, José Afonso. Direito Ambiental Constitucional. São Paulo: Malheiros, 1994, p 207.

19 MILARÉ, 1995, p. 207 
Id on Line Revista Multidisciplinar e de Psicoloqia

Id on Line Revista Multidisciplinar e de Psicologia

\section{Distinção Entre Dano Ambiental e Dano Ecológico}

No entendimento de Porfírio Júnior (2002), é necessário a distinção entre os conceitos de dano ambiental e de dano ecológico, sendo que para ele o dano ecológico é considerado apenas as lesões causadas aos elementos naturais do meio ambiente, ainda que estes não resultem necessariamente em prejuízos patrimoniais diretos e indiretos. A distinção se justifica, segundo o autor, pelo fato de que se faz importante para o estudo da responsabilidade estatal, pois, o dano ambiental atinge bens e interesses difusos. ${ }^{20}$

Nesta perspectiva o dano ambiental é, em princípio, um dano sofrido pelo conjunto do meio natural ou por um de seus componentes levando em conta como patrimônio coletivo independentemente de suas repercussões sobre pessoas e bens.

Entretanto, Paulo Machado (1998) considera excessivo afirmar que todas as alterações no meio ambiente vão ocasionar um prejuízo, pois, dessa forma, estaríamos negando a possibilidade de mudança e de inovação, demonstrado que a presença de admitirmos mudanças espontâneas ou até provocadas pela natureza, não querendo, com isso, afirmar que todas essas mudanças sejam benéficas. 21

\section{Características do Dano Ambiental}

Edis Milaré (2001) inova ao tratar a de características específicas do Dano Ambiental, e apresenta o assunto de forma clara - As características por ele apontadas tornaram praticamente uma unanimidade no assunto, e as poucas divergências existentes na doutrina simplesmente acrescentam às características apontadas pelo douto supracitado. Com isso, são elas:

\section{Pulverização de vítimas}

Contrapõe-se o dano ambiental ao dano comum pelo fato de que, enquanto este atinge uma pessoa ou um conjunto individualizado de vítimas, aquele atinge, necessariamente, uma coletividade difusa de vítimas, "mesmo quando alguns aspectos particulares da sua danosidade atingem individualmente certos sujeitos"22

${ }^{20}$ PORFIRIO JÚNIOR, Nelson Freitas. Responsabilidade do Estado Em Face do Dano Ambiental. São Paulo: Malheiros Editores, 2002, p. 51.

21 MACHADO, 1998, p. 279.

${ }^{22}$ MILARÉ, 2001, p. 427-428 
Id on Line Revista Multidisciplinar e de Psicoloqia

Id on Line Revista Multidisciplinar e de Psicologia

\section{Difícil reparação}

$\mathrm{Na}$ grande maioria dos casos de dano ambiental, a reparação ao status quo ante é quase impossível e a mera reparação pecuniária é sempre insuficiente e incapaz de recompor o dano.

\section{Difícil valoração}

Nem sempre é possível calcular o dano ambiental, justamente em virtude de sua irreparabilidade. Édis Milaré ${ }^{23}$ salienta que essa característica ficou mais complexa, principalmente com o advento da Lei 8.884 de 11 de junho de 1994 que, em seu art. 88, alterou o caput do art. $1^{\circ}$ da Lei 7.347/85, ensejando que também os danos morais coletivos sejam objetos das ações de responsabilidade civil em matéria de tutela de interesses transindividuais.

Há, ainda, uma corrente mencionada por William Freire (2002) que reclama a existência de três características do dano ambiental necessários à configuração do dever de indenizar: a sua anormalidade, que existe onde houver modificação das propriedades físicas e químicas dos elementos naturais, de tal grandeza que estes percam, parcial ou totalmente, sua propriedade ao uso; a sua periodicidade, não bastando eventual emissão poluidora; e a sua gravidade, devendo ocorrer transposição daquele limite máximo de absorção de agressões que possuem os seres humanos e os elementos naturais. $^{24}$

Alguns doutrinadores ainda apontam outras três características na ocorrência do dano ambiental: a primeira delas é a sua anormalidade, pelo fato da ação provocar modificações nas propriedades físicas e químicas dos elementos naturais, pois estes perdem, parcial ou totalmente, sua propriedade ao uso, outra característica apontada é a gravidade, pois, ocorre transposição daquele limite máximo de absorção de agressões que possuem os seres humanos e os elementos naturais. ${ }^{25}$

\section{Reparação do Dano Ambiental}

A Constituição Federal, em seu art. 225, § 2o, determina que: "aquele que explorar recursos minerais fica obrigado a recuperar o meio ambiente degradado, de acordo com a solução técnica exigida pelo órgão público competente, na forma da lei." O § 3o acrescenta: "as condutas e atividades consideradas lesivas ao meio ambiente sujeitarão os infratores, pessoas físicas ou jurídicas, a sanções penais e administrativas, independentemente da obrigação de reparar o dano".

A questão é que no Direito Ambiental na ocorrência do dano, não basta indenizar, mas o desafio está em fazer com que a causa do mal cesse, como o autor Paulo Machado (1998, p. 273-274).

\footnotetext{
${ }^{23}$ Ibid, p. 423

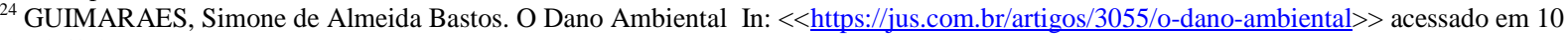
de abril de 2016

${ }^{25}$ MILARÉ, Op. Cit, p. 51.
} 
Id on Line Revista Multidisciplinar e de Psicoloqia

Id on Line Revista Multidisciplinar e de Psicologia

Assim, só haverá a obrigação da reparação pecuniária, se for impossível a recomposição do meio ambiente, uma vez que este é o objetivo principal. Nesta situação configura-se o dano causado ao meio ambiente, cujas repercussões afetam o homem de forma indireta. ${ }^{26}$

Em consonância com esta ideia, Paulo Bessa Antunes (2005) adverte: “o responsável pelo dano tem o dever de repará-lo o mais amplamente possível. Reparar o dano significa a busca de um determinado valor que se possa ter como equivalente ao dano causado por aquele que praticou o ato ilícito." ${ }^{27}$

Paulo Bessa Antunes (2005), ainda afirma que as sanções penais e administrativas têm um caráter de castigo. Por outro lado, a reparação do dano busca a recomposição daquilo que foi destruído, quando possível. Ambas as hipóteses procuram impor um custo ao poluidor e cumprem dois objetivos principais: dar uma resposta econômica aos danos sofridos pela vítima e dissuadir comportamentos semelhantes do poluidor ou terceiros. ${ }^{28}$

O doutrinador Paulo Machado (1998) ainda acrescenta que no seu entender é "injurídico o Poder Público se omitir em indenizar integralmente, limitando-se através de um teto, aceitando, entretanto, um risco limitado"29.

\section{A Responsabilidade do Estado decorrente do Dano Ambiental}

\section{Considerações preliminares}

Parte da doutrina classifica o direito em gerações distintas, sendo que a referida classificação posiciona os direitos fundamentais como sendo de primeira geração, os direitos sociais sendo o de segunda geração. Para Norberto Bobbio (1992) ao lado dos direitos, que foram chamados de direitos da segunda geração, emergiram hoje os chamados direitos da terceira geração, estes reivindicados pelos movimentos ecológicos: o direito de viver num ambiente não poluído. Assim, diante do crescente desenvolvimento tecnológico e científico, que afetam as relações socioeconômicas e são marcados pela participação da sociedade, preocupada com a noção de preservacionismo ambiental e as dificuldades para a proteção dos consumidores, e ressaltando ainda, a postura de Bobbio, "o ser humano está inserido em uma coletividade e passa a ter direitos de solidariedade." ${ }^{30}$ Posicionando deste modo, o direito ao meio ambiente como os direitos transindividuais ou difusos.

O doutrinador português Canotilho (1991) tem posicionamento semelhante ao defendido por Bobbio, ao considerar no início da década de 90, o direito de Quarta Geração:

\footnotetext{
${ }^{26}$ PORFIRIO JUNIOR, 2002, p. 53

27 ANTUNES, Paulo de Bessa. Direito Ambiental. $8^{\text {a }}$ ed. Rio de Janeiro: Editora Lumen Juris, 2005, p.139

28 Ibid, $p 143$

29 MACHADO, Paulo Afonso Leme. Direito Ambiental Brasileiro. $7^{\text {a }}$ ed. São Paulo: Malheiros Editores, 1998, p. 283.

${ }^{30}$ BOBBIO, Norberto. A era dos direitos, Tradução de Carlos Nelson Coutinho. Rio de Janeiro: Campus, 1992 p. 6 
São os direitos de quarta geração (...) que abrangem as suas sucessivas sedimentações históricas ao longo do tempo, perpassando os tradicionais direitos negativos, conquista da revolução liberal; os direitos de participação política, emergentes da superação democrática do Estado Liberal; os direitos positivos de natureza econômica, social e cultural (direitos sociais), constituintes da concepção social do Estado; finalmente os direitos de quarta geração, como o direito ao meio ambiente e a qualidade de vida. ${ }^{31}$

A teoria da responsabilidade objetiva, no que diz respeito a responsabilização pelo Dano Ambiental, está assentada na teoria do risco que determina o dever de indenizar àquele que exerce qualquer atividade perigosa. Para que se prove a existência da responsabilidade por danos ambientais, basta a comprovação do dano existente e o nexo causal, que nada mais é do que a relação entre a ocorrência do dano e a fonte que a causou. Vale ressaltar que havendo mais de uma fonte a responsabilidade será solidária, pois o ônus da atividade é o dever de reparar os danos praticados, sendo certo que a culpa não precisará ser provada.

Em torno da questão do direito ambiental brasileiro, prevalece à regra da responsabilidade objetiva, que prescinde de culpa, ou seja, para pleitear a reparação do dano, basta que seja demonstrado a presença do nexo causal entre a conduta do réu e a lesão ao meio ambiente a ser protegido. Portanto, três são os pressupostos considerados para que a responsabilidade ocorra: a ação ou omissão do réu; o evento danoso e a relação de causalidade.

Vale ressaltar que não é nenhum conceito novo, pois na legislação o instituto da Responsabilidade Objetiva na seara do Direito Ambiental já está presente a um bom tempo - A exemplo disso, pode-se citar a Lei n. ${ }^{\circ}$ 6.983/81, que dispõe sobre a Política Nacional do Meio Ambiente e seus fins, que em seu art. 14 , parágrafo $1^{\circ}$, estabelece:

Parágrafo $1^{\circ}$ - Sem obstar a aplicação das penalidades previstas neste artigo, é o poluidor obrigado, independentemente da existência de culpa, a indenizar ou reparar os danos causados ao meio ambiente e a terceiros, afetados por sua atividade. $\mathrm{O}$ Ministério Público da União e dos Estados terá legitimidade para propor ação de responsabilidade civil e criminal, por danos causados ao meio ambiente.

A norma em questão funciona, primordialmente, na tentativa de equilibrar a agressão ao meio ambiente e sua correspondente reparação, procurando criar maiores possibilidades de que se reparem os danos eventualmente ocorridos. Tarefa bastante difícil, apesar das disposições da lei, e que certamente exige uma atuação rigorosa e efetiva de todos operadores jurídicos envolvidos no contexto da proteção ambiental.

\footnotetext{
${ }^{31}$ CANOTILHO, J.J.Gomes; MOREIRA, Vital. Fundamentos da constituição. Coimbra: Coimbra Ed., 1991. 
Id on Line Revista Multidisciplinar e de Psicoloqia

Id on Line Revista Multidisciplinar e de Psicologia

\section{A Empresa Samarco}

Como o vinculado no portal da empresa, a Samarco é brasileira voltada para a área de mineração, de capital fechado, controlada em partes iguais por dois acionistas: BHP Billiton Brasil Ltda. e Vale S.A., tendo como produto principal as pelotas de minério de ferro comercializadas para a indústria siderúrgica mundial, exportando inclusive para 19 países das Américas, Oriente Médio, Ásia e Europa. A empresa, ainda destaca, que a sua missão é produzir e fornecer pelotas de minério de ferro, aplicando tecnologia de forma intensiva para otimizar o uso de recursos naturais e gerando desenvolvimento econômico e social, com respeito ao meio ambiente. Tendo como valores o Respeito às pessoas, Respeitando o direito à individualidade, sem discriminação de qualquer natureza, e honramos, com nossa responsabilidade, o bem-estar das pessoas e da sociedade, assim como o cuidado com o meio ambiente, por meio da utilização correta dos recursos necessários às nossas atividades. Acreditando inclusive, em seu papel influenciador e contributivo para o desenvolvimento social e econômico do País, visando ao futuro das próximas gerações. Outro valor informado no site da empresa é a integridade no cumprimento às leis e respeito aos princípios morais, primando pela dignidade e ética nas relações e ainda, buscam constantemente o conhecimento e a geração de ideias inovadoras, para o atingimento de resultados diferenciados e duradouros. ${ }^{32}$

\section{A Responsabilidade Administrativa no caso envolvendo a Samarco}

Na legislação pátria a responsabilidade administrativa aparece com frequência, a exemplo, do que reza o Art. 70 da Lei $n^{\circ} 9.605$ de 12 de fevereiro de 1998 que assevera: considera-se infração administrativa ambiental toda ação ou omissão que viole as regras jurídicas de uso, gozo, promoção, proteção e recuperação do meio ambiente.

A Constituição de 1946 em seu artigo 184, já havia a previsão para a responsabilidade objetiva ao Estado. Seguindo o mesmo entendimento, nos artigos 554 e 555 do Código Civil de 1916, com a mesma ideia presente nos artigos 1.277 e 1.280 do Código Civil de 2002, tratando dos direitos de vizinhança, contemplaram a responsabilidade civil ambiental objetiva pelo uso nocivo da propriedade.

No dizer de Antônio Herman V. Benjamin (1998): "O Direito Ambiental Nacional, a partir da Lei $\mathrm{n}^{\circ} 6.938 / 81$, passa a proteger o individual a partir do coletivo. Daí, sua natureza essencialmente pública". ${ }^{33}$

Seguindo esta tendência, a própria Constituição Federal de 1988 incorporou a responsabilidade objetiva ambiental, proclamada pela legislação ordinária, ao mencionar no parágrafo

${ }^{32}$ Samarco. Disponível em http://www.samarco.com/institucional/a-empresa/ Acesso em 23 de abril de 2016.

33 BENJAMIN, Antônio Hermann V. Responsabilidade Civil pelo Dano Ambiental. Revista de Direito Ambiental. $\mathrm{n}^{\circ}$ 9. São Paulo: Revista dos Tribunais, 1998. p. 36 
Id on Line Revista Multidisciplinar e de Psicologia

Id on Line Revista Multidisciplinar e de Psicologia

$3^{\text {o }}$ do seu artigo 225, que "as condutas e atividades consideradas lesivas ao meio ambiente sujeitarão os degradadores a reparar os danos causados", não fazendo, portanto, qualquer menção da existência de culpa na atuação do agente causador da degradação ambiental.

Também, o novo Código Civil Brasileiro, em seu artigo 927, parágrafo único, estabelece a obrigação de reparar o dano, independentemente de culpa, fica obrigado de repará-lo, em lei, quem causou o dano quando a atividade normalmente desenvolvida implicar, por sua natureza, risco para os direitos de outrem.

Neste contexto a legislação brasileira está fundamentada na teoria da responsabilidade objetiva, quando trata à responsabilização decorrente de danos ambientais, tendo como base a teoria do risco, segundo a qual cabe o dever de indenizar àquele que exerce atividade perigosa, consubstanciando ônus de sua atividade o dever de reparar os danos por ela causados, e assim, para que se "prove a existência da responsabilidade por danos ambientais, basta a comprovação do dano existente e do nexo causal. Deste modo, a culpa não precisará ser provada, como assevera Renata Martins (2007). ${ }^{34}$

\section{Com efeito, aponta Francisco Marques Sampaio:}

Como já vimos, os danos ao meio ambiente se constituem em uma das hipóteses em que o legislador considerou conveniente e oportuno excluir a ilicitude da ação ou da omissão como pressuposto da obrigação de ressarcimento. Restam, portanto, no caso do dano ambiental, três requisitos para que a responsabilidade possa estar suficiente caracterizada: o fato, o dano e o liame ou nexo de causalidade entre o fato e o dano. $^{35}$

Vale ainda ressaltar, as hipóteses também presentes nos incisos I,II,III,IV do artigo 14 da Lei 6.938 de 1981 que possuem previsões de sanções administrativas pelo órgão competente, os seja, a sanção sempre deve estar prevista em lei, obedecendo portanto, o princípio da legalidade que constitui no princípio informador dos atos administrativos.

Conforme o professor Nelson Nery Júnior citado na obra de Fiorillo (2004):

O fato de a administração dever agir somente no sentido positivo da lei, isto é, quando the é por ela permitido, indica a incidência da cláusula due process no direito administrativo. A doutrina norte-americana tem-se ocupado do tema, dizendo ser manifestação do princípio do devido processo legal e o controle dos atos administrativos, pela própria administração e pela via judicial. Os limites do poder de polícia da Administração são controlados pela cláusula do due process. ${ }^{36}$

Nesta linha, o Art. $2^{\circ}$ do Código de Mineração prevê que o Poder Público é responsável pela Autorização de Pesquisa, Concessão da Lavra e Permissão de Lavra Garimpeira, e ainda, conforme o

\footnotetext{
${ }^{34}$ MARTINS, Renata de Freitas. Responsabilidade Civil Ambiental. Direção geral de Antônio Silveira Ribeiro dos Santos. Disponível: <http://www.aultimaarcadenoe.com/direitoresponsabilidade.htm>, acessado em: 07 abril 2016.

35 SAMPAIO apud VITTA, 2000, p. 26

${ }^{36}$ NERY JUNIOR apud FIORILLO, 2004, p. 45.
} 
Id on Line Revista Multidisciplinar e de Psicoloqia

Id on Line Revista Multidisciplinar e de Psicologia

Art. $7^{\circ}$ do mesmo Código, a concessão é efetivada pelo Departamento Nacional de Produção Mineral ou pelo Ministro de Estado de Minas e Energia, de acordo ao procedimento utilizado.

Deste modo, a partir da constatação do dano pelos órgãos de fiscalização ambiental, é realizada lavratura do Boletim de Ocorrência Ambiental e do Auto de Infração. Nessa hipótese, se inicia a apuração das responsabilidades administrativas, civil e penal, pois as cópias destes documentos são encaminhadas ao Ministério Público que fará a abertura do inquérito civil, e cópias e são remetidas, por este órgão, para a autoridade policial instaurar o pertinente procedimento.

$\mathrm{Na}$ vertente administrativa, se percebido a existência do dano ambiental pelos órgãos que teoricamente se responsabilizam pela fiscalização ambiental da infração, isso pode influenciar na tomada de medidas administrativas prévias - No caso em tela, o Departamento Nacional de Produção Mineral é órgão responsável por esta fiscalização

Uma vez que o Estado tem o dever de exercer o poder de polícia administrativa ambiental, ao fiscalizar os serviços, sendo papel do Departamento Nacional de Produção Mineral - DNPM, órgão que fazia parte do Ministério de Minas e Energia, mas com a vigência da Lei 8.876, de 1994, o referido departamento foi elevado a personalidade jurídica de autarquia, tendo portanto, autonomia administrativa e financeira.

Entretanto, apenas após todo o procedimento realizado na esfera administrativa, com a presença do contraditório e da ampla defesa, é que poderá ser imposta a penalidade, desde que esta seja o resultado indicado após a constatação das circunstancias para o caso concreto.

Após o evento ocorrido no Estado de Minas Gerais foi noticiado que a referida fiscalização foi exercida de forma precária, em razão do referido órgão responsável só dispor de 12 técnicos, incumbidos de fiscalizar reservatórios, no caso, de rejeitos do minério. Ainda assim, a referida matéria jornalística informa que de janeiro a outubro de 2015 foram realizadas 61 inspeções nos 663 reservatórios existentes. ${ }^{37}$ (Duarte, 2015)

Porfírio Junior (2002) assevera que quando a divergência que havia na doutrina se a responsabilidade era objetiva ou subjetiva, os juristas começaram a questionar a respeito da adoção da teoria do risco integral, e outros almejava que fosse introduzida a teoria do risco administrativo, ou risco criado. Com isso, estava delineado uma celeuma em torno desta discussão, pois os mesmos defensores da teoria do risco integral sempre admitiram a exclusão da responsabilidade estatal em casos de força maior ou de culpa ou dolo da vítima.

Seguindo o direcionamento de Porfírio Júnior (2002) ele afirma que até hoje entre os doutrinadores brasileiros há controvérsias a respeito da responsabilidade do Estado pelo dano ambiental reside no apoio à teoria do risco integral em sua forma pura - como o fazem Rodolfo de Camargo Mancuso e Nelson Nery Júnior - ou em uma das variantes - como fazem Edis Milaré e

37 DUARTE, Felipe Simões. O caso Samarco e a responsabilidade ambiental. Disponível em: http://fellipesd.jusbrasil.com.br/artigos/255747257/o-caso-samarco-e-a-responsabilidade-ambiental. Acessado em 11 de abril, 2016. 
Id on Line Revista Multidisciplinar e de Psicoloqia

Id on Line Revista Multidisciplinar e de Psicologia

Toshio Mukai - que é a teoria do risco-proveito ou risco criado, originária diretamente do princípio do poluidor-pagador: quem obtém lucros com determinada atividade deve arcar também com os prejuízos causados à Natureza, evitando assim, a privatização dos lucros e socialização dos prejuízos. Deste modo, esta teoria se aproxima da teoria denominada de risco administrativo, pois, admite também as excludentes da força maior e da culpa da vítima. ${ }^{38}$

Para Porfírio Júnior (2002) todo o ato comissivo da Administração que resulte em dano ao meio ambiente aspira sua responsabilidade objetiva, admitindo apenas a excludente da força maior, que também pode ser compreendida como fato ou evento não decorrente de ação da Administração. ${ }^{39}$

Entretanto, ainda no entendimento de Porfírio Júnior, a doutrina se posiciona ao lado do princípio da responsabilidade subjetiva, uma vez que se o Estado não agiu não pode este ser o autor do dano. Assim, cabe responsabilização ao Estado caso este seja o responsável por impedir que o dano ocorra. Assim, faz sentido responsabilizá-lo se este descumpriu dever legal que lhe impunha evitar o evento que causou lesão ao meio ambiente.

Dentro desta hipótese Bandeira de Mello (1999) defende: "Não bastará, então, para configurar-se responsabilidade estatal, a simples relação entre a ausência do serviço (omissão estatal) e o dano sofrido". ${ }^{40}$ Com isso, o Poder Público deve ser regido pelo dever/poder de cautela, com o exercício do seu poder de polícia, pois, agindo de modo a prevenir a ocorrência do dano no caso concreto.

Toshio Mukai (1998) adverte que comumente os tribunais têm analisado situações em que a Administração se omite de realizar a limpeza de boca-de-lobo, galerias de águas pluviais e da canalização de córregos que não fora efetivada a tempo e em decorrência de chuvas intensas ocorre inundações, este é um exemplo, que resulta da omissão dos agentes públicos, no caso em que o Estado tem o dever jurídico de agir e não o faz, ou o faz de forma inadequada ou tardiamente.41

Deste modo, na responsabilidade do Estado por conduta omissiva, o agente público tem o dever de agir no caso concreto, estabelecido em lei, mas se não o faz, desobedecendo ao preceito legal. E não agindo, causa dano ao meio ambiente. Então neste caso apresenta uma conduta ilícita, isto é contrariando uma norma legal, contraria a lei, ferindo o princípio da legalidade.

Com isso, o Estado responde sim pelos atos e serviços omissivos que venham lesionar o meio ambiente, tendo que comprovar a culpa pelo dano, o que caracteriza a teoria da responsabilidade subjetiva do Estado. Assim, a aplicação da responsabilização serve fundamentalmente para prevenir abusos por parte da Administração Pública e também ressarcir, caso seja possível, os danos causados.

\footnotetext{
${ }^{38}$ PORFÍRIO JR. 2002, p. 68-69

39 Ibid, p.69

${ }^{40}$ MELLO, Celso Antônio Bandeira de. Curso de Direito Administrativo. 11 ed. São Paulo: Malheiros Editores, 1999, p, 854-855.

${ }^{41}$ MUKAI, Toshio (1998). Direito ambiental sistematizado. $3^{\mathrm{a}}$. edição. Rio de Janeiro: Forense Universitária, $200 \mathrm{p}, 1998, \mathrm{p}, 74$. 
Id on Line Revista Multidisciplinar e de Psicoloqia

Id on Line Revista Multidisciplinar e de Psicologia

\section{Jurisprudência que tratam de casos semelhantes}

O evento ocorrido com a mineradora Samarco é um evento recente, com isso, ainda não foi exarado nenhuma decisão por tribunais ou pela Corte Suprema em relação a esse caso concreto. Com isso, vamos apreciar algumas decisões que demonstra posicionamento da jurisprudência em casos semelhantes, dos quais podemos depreender que não há por parte da jurisprudência um entendimento consolidado, em relação a aplicação da tese da responsabilidade objetiva ou da responsabilidade solidária, assim, como o reconhecimento da legitimidade da Administração Pública para a imposição de multas e penalidades, até mesmo a interdição de estabelecimento ou atividade é entendimento pacífico.

Dentre alguns julgamentos referentes ao tema se destacam, o Recurso Especial n ${ }^{\circ}$ 647493/SC, que considerou a União solidariamente responsável pelos danos causados ao meio ambiente, por omissão no seu dever de fiscalizar as empresas mineradoras que funcionaram ao longo de duas décadas. A decisão, até então inédita que condenou a União, juntamente com as empresas poluidoras e seus sócios administradores, a recuperar área degradada no sul de Santa Catarina. Além do mais, os ministros da $2^{\text {a }}$ Turma confirmaram, ainda, que as ações coletivas de reparação de danos ambientais são imprescritíveis. ${ }^{42}$

Entendimento semelhante pode ser adotado no caso Samarco, se provada a omissão do Estado no cumprimento do seu dever de fiscalizar, como o que ocorreu no caso do Sul de Santa Catarina, no voto do relator ministro João Otávio de Noronha, entendeu que a União tem o dever de fiscalizar as atividades relacionadas à extração mineral e, se não o faz, responde subjetivamente pela poluição ambiental. No entanto, o relator ressalvou que, apesar da solidariedade do Poder Público, as mineradoras é que devem arcar integralmente com os custos da recuperação ambiental e caso a União o fizer, deverá buscar junto às empresas poluidoras o ressarcimento que depender, uma vez que, embora omisso, o Estado não agariou proveito no dano.

Ademais, o Ministro João Otávio Noronha considera que em contrapartida com a maioria da doutrina que a responsabilidade do Estado por omissão é subjetiva, mesmo em se tratando de responsabilidade por dano ao meio ambiente, uma vez que a ilicitude no comportamento omissivo é aferida sob a perspectiva de que deveria o Estado ter agido conforme a lei, ficando, portanto, neste recurso, condenada a União a reparação ao meio ambiente, arcando com os custos configurando deste modo uma espécie de auto-indenização.

\footnotetext{
${ }^{42}$ BRASIL. Supremo Tribunal de Justiça, $2^{\text {a }}$ Turma, Resp n ${ }^{\circ}$ 647493/SC, Relator Ministro João Otávio de Noronha, DJ 22-10-2007. Disponível em:

$<$ https://ww2.stj.jus.br/jurisprudencia/externo/informativo/?acao=pesquisar\&livre=MINERADORA+ESTADO\&operador=e\&b=INFJ\&thesa urus=JURIDICO $>$ Acessado em 11 abril de 2016 
Id on Line Revista Multidisciplinar e de Psicoloqia

Id on Line Revista Multidisciplinar e de Psicologia

Em consonância com a Resp $n^{\circ}$ 604725/PR, outro julgado que merece destaque, trata a responsabilidade Objetiva independente da existência da culpa, o polidor, ainda que indireto (Estadorecorrente) é obrigado a indenizar e reparar o dano causado ao meio ambiente.

O Ministro Castro Meira acentua:

Não o fazendo, a Administração se torna civilmente responsável por eventuais danos sofridos por terceiros em virtude de sua ação (permitindo o exercício da atividade poluente, em desacordo com a legislação vigorante) ou de sua omissão. ${ }^{43}$

No caso específico devemos conceituar o significado do Dano Ambiental, como assevera Renata de Freitas Martins (2007), para maior compreensão do tema: assim, não apenas a agressão à natureza que deve ser objeto de reparação, mas também a privação do equilíbrio ecológico, do bem estar e da qualidade de vida imposta à coletividade. ${ }^{44}$

Outro julgado que demonstra que não há unidade nas decisões dos órgãos superiores: "em matéria de proteção ambiental, há responsabilidade civil do Estado quando a omissão de cumprimento adequado do seu dever de fiscalizar for determinante para a concretização ou o agravamento do dano causado pelo seu causador direto." (AGRESP 200702476534, Relator Ministro Teori Albino Zavascki, STJ - $1^{\text {a }}$ Turma, DJE: 04/10/2011)

No entender de Antunes(2005),

Os tribunais brasileiros têm tido uma compreensão extremamente restrita do conceito de dano ambiental e, por consequência do bem jurídico meio ambiente.. Em geral eles tem adotado uma postura que exige o dano real e não apenas o dano potencial(...) O próprio risco, no qual se funda a responsabilidade ambiental, não é muito considerada pois, ao que parece, é necessário que o risco se materialize em um "acidente" para que seja efetivamente reparado. Concretamente, o Poder Judiciário está abdicando de sua função cautelar em favor de uma atividade puramente repressiva que, em Direito Ambiental, é de eficácia discutível. ${ }^{45}$

O autor Porfírio Júnior (2002), aponta que a nossa legislação está entre as mais avanças do mundo em matéria de proteção ao meio ambiente, inclusive os instrumentos processuais como a Ação Civil Pública e a Ação Popular, são tidos como modelos a serem seguidos em diversos países, no entanto, ainda assim, é notório que a degradação do meio ambiente tem atingido altos níveis, e este problema grave ele atribui como principais causas a questão da falta de estrutura dos órgãos voltados a administração ambiental, e o outro fator que facilita a degradação ambiental é a falta de educação ambiental da população. ${ }^{46}$

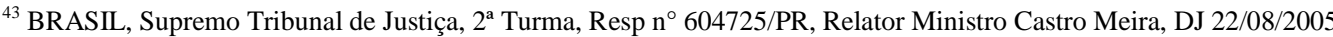

${ }^{44}$ MARTINS, Renata de Freitas. Responsabilidade Civil Ambiental. Direção geral: Antônio Silveira Ribeiro dos Santos. Disponível: <http://www.aultimaarcadenoe.com/direitoresponsabilidade.htm>, acessado em: 07 abril de 2016

45 ANTUNES, 2005, p 148-149.

46 PORFÍRIO JUNIOR, 2002, p.73. 
Id on Line Revista Multidisciplinar e de Psicoloqia

Id on Line Revista Multidisciplinar e de Psicologia

A tendência da doutrina configura-se no sentido de não acatar as clássicas excludentes da responsabilidade civil, indicando cinco consequências que decorrem da aceitação da responsabilidade civil, quando se refere à questão ambiental, sendo elas: irrelevância da intenção danosa (basta o prejuízo); irrelevância da mensuração do subjetivismo; inversão do ônus da prova; irrelevância da licitude da atividade; atenuação do relevo do nexo casual.

\section{Considerações Finais}

Diante dos julgamentos e da doutrina tratados neste estudo é possível depreender que não há um entendimento consolidado em torno do tema, sendo necessário outros estudos. Ademais, a responsabilidade pelo dano ambiental deve se concentrar no princípio da prevenção, uma vez que a reparação do dano nem sempre é possível, pois, na maioria das vezes, a reparação apresenta-se incompleta ou insuficiente, e quando ela é possível será demasiadamente onerosa, como adverte Edis Milaré (2001) em sua obra clássica.

Nessa direção leciona Nelson Porfírio Júnior (2002):

O Estado deve assumir papel preponderante no sentido de garantir a qualidade do meio ambiente, ampliando-se sua responsabilidade em face do dano ambiental, para que seja compreendida não só a acepção de reparação ou recomposição, mas também enquanto obrigação de prevenir sua ocorrência. ${ }^{47}$

A sociedade precisa ser acompanhada pelo direito, até porque poucas são as atividades humanas que não demandam da incidência do Direito Ambiental. Deste modo, a linha de abrangência apresenta-se vasta e merecedor de discussões, para que haja um maior aperfeiçoamento dos instrumentos jurídicos disponíveis, com isso, se estes instrumentos fossem mais efetivos eventos como o ocorrido no interior do Estado de Minas Gerais provavelmente poderiam ter seus efeitos minorados, ou mesmo evitados. Com isso, pode o Estado ser responsabilizado pelo dano ambiental da Samarco caso demonstre que a ausência de fiscalização por parte do Estado ou mesmo fiscalizações realizadas sem critérios técnicos, gerando com isso a responsabilidade administrativa, no entanto, no caso concreto é necessário aguardar o resultado das investigações e o posicionamento dos julgadores.

Ademais, os danos causados ao meio ambiente poderão ser tutelados por instrumentos jurídicos diversos, destacando a Ação Civil Pública, a Ação Popular e o Mandato de Segurança Coletivo. E ainda, como uma alternativa moderna, os acordos ambientais apresentam-se de forma concreta para garantir uma qualidade ambiental mediante um desenvolvimento sustentável, com a finalidade de não causar prejuízo ao bem coletivo.

47 PORFIRIO JUNIOR, Nelson Freitas. Responsabilidade do Estado em face do Dano Ambiental. São Paulo: Malheiros Editores, 2002.p. 116 
Id on Line Revista Multidisciplinar e de Psicologia

Id on Line Revista Multidisciplinar e de Psicologia

Corroboro com Porfírio Júnior (2002, p. 117) ao afirmar que é necessário a existência de um novo tipo de responsabilidade para a questão ambiental, na qual, predomine o instituto da responsabilidade objetiva, e também a responsabilidade solidária na hipótese de participação plural para a ocorrência do dano e cabendo ao poluidor/agente a inversão da prova, sendo portanto, atenuado a existência do nexo causal. Além do mais, não raras vezes, o Estado não consegue acompanhar as exigências da sociedade, quando se torna relevante a responsabilidade estatal por danos ambientais em que lhe pode ser imputado ato omissivo.

Assim, o direito ambiental se constitui como importante instrumento jurídico na tutela dos bens difusos, vez que os danos ao meio ambiente possuem uma elevada danosidade social, por colocar em risco não apenas a vida e saúde dos indivíduos e a perpetuação da espécie humana, mas a própria natureza que deve ser preservada e objeto de tutela pelo que representa para a presente e para as futuras gerações. Com isso, esse é um tema merecedor de maior amadurecimento

Destarte, pode-se dizer que o artigo teve como pueril intuito, chamar a atenção para a necessidade responsabilizar o Estado de forma mais intensa pelos danos causados ao meio ambiente. Buscou-se ainda, através das linhas tímidas e palidamente escritas, responder às questões inicialmente propostas a fim de, ao menos, tentar manter acessas as chamas da inquietação e da reflexão crítica que são elementos indispensáveis à formação do alicerce de um pensamento jurídico capaz de contribuir para a redução das injustiças existentes no mundo hodierno, para que eventos semelhantes ao ocorrido no Estado de Minhas não se repitam.

\section{Referências}

AFONSO DA SILVA, José. Curso de Direito Constitucional Positivo. São Paulo: Malheiros, 2003

ANTUNES, Paulo de Bessa. Direito Ambiental. $8^{a}$ ed. Rio de Janeiro: Editora Lumen Juris, 2005.

BRASIL, Constituição Federal (1988) 27º edição. São Paulo: Saraiva, 2001.

BRASIL. Supremo Tribunal de Justiça, $2^{\text {a }}$ Turma, Resp $n^{\circ}$ 647493/SC, Relator Ministro João Otávio de Noronha, DJ 22-10-2007.

BRASIL, Supremo Tribunal de Justiça, $2^{\text {a }}$ Turma, Resp n ${ }^{\circ}$ 604725/PR, Relator Ministro Castro Meira, DJ 22/08/2005.

BUTZKE, Alindo. O Dano Ambiental Indenizável e o Dever de Reparação do Estado. Disponível: $\quad<$ http://www.rlcu.org.ar/destacados/clea/ponencias/I\%20Encuentro\%20RLCUButske\%20III.pdf> , acesso 10 abril 2016

BOBBIO, Norberto. A era dos direitos. Tradução de Carlos Nelson Coutinho. Rio de Janeiro: Campus, 1992. 
Id on Line Revista Multidisciplinar e de Psicoloqia

Id on Line Revista Multidisciplinar e de Psicologia

CANOTILHO, J.J.Gomes; MOREIRA, Vital. Fundamentos da constituição. Coimbra: Coimbra Ed., 1991.

CARVALHO NETO, Inácio de. Responsabilidade do Estado por ato de seus agentes. São Paulo: Atlas, 2000

CAVAlieri FILHO, Sergio. Programa de Responsabilidade Civil. $2^{\mathrm{a}}$ ed. $3^{\mathrm{a}}$ tir. São Paulo: Malheiros Editores. 1999.

DI PIETRO, Maria Sylvia Zanella. Direito Administrativo. 20 ed. São Paulo: Atlas, 2007.

DUARTE, Felipe Simões. O caso Samarco e a responsabilidade ambiental. Disponível em: http://fellipesd.jusbrasil.com.br/artigos/255747257/o-caso-samarco-e-a-responsabilidade-ambiental.

Acesso em 11 de abril, 2016.

FIORILLO, Celso Antonio Pacheco. Curso de Direito Ambiental Brasileiro. 5a ed. São Paulo: Editora Saraiva. 2004.

FREITAS, Juarez (org.). Responsabilidade Civil do Estado. São Paulo: Malheiros Editores, 2006.

GASPARINI, Diógenes. Direito Administrativo. $8^{\circ}$ ed. São Paulo: Saraiva. 2003.

GUIMARAES, Simone de Almeida Bastos. O Dano Ambiental. Disponível In: <http://jus2.uol.com.br/doutrina/texto.asp?id=3055> Acesso: 10 de abril de 2016.

MACHADO, Paulo Afonso Leme. Direito Ambiental Brasileiro. $7^{\mathrm{a}}$ ed. São Paulo: Malheiros Editores, 1998.

MEIRELLES, Hely Lopes. Direito Administrativo Brasileiro. 30 ed. São Paulo: Malheiros Editores, 2005 .

\section{Proteção Ambiental e Ação Civil Pública. RT 611/11}

MELLO, Celso Antônio Bandeira de. Curso de Direito Administrativo. 11 ed. São Paulo: Malheiros Editores, 1999.

MILARÉ, Édis. Direito do Ambiente. Doutrina, prática, jurisprudência, glossário. 2. ed. São Paulo: RT, 2001.

MUKAI, Toshio (1998). Direito ambiental sistematizado. $3^{\text {a }}$. edição. Rio de Janeiro: Forense Universitária, 200p, 1998.

PORFIRIO JUNIOR, Nelson Freitas. Responsabilidade do Estado Em Face do Dano Ambiental. São Paulo: Malheiros Editores, 2002.

SAMPAIO, Francisco José Marques. Responsabilidade Civil e Reparação de danos ao Meio Ambiente. Rio de Janeiro: Lumen Juris, 1998.

SILVA, José Afonso da. Direito Ambiental Constitucional. $3^{\text {a }}$ ed São Paulo: Malheiros Editores, 2000.

UFRJ. Revista do Instituto Virtual Internacional de Mudanças Globais, Disponível em: http://www.ivig.coppe.ufrj.br/index.php. Acessado em 11 de abril de 2016. 


\section{Como citar este artigo (Formato ABNT):}

LOPES, J.O.; FERREIRA, L.C. Responsabilidade do estado em face dos danos Ambientais: Um olhar sobre o Caso da SAMARCO. Id on Line Revista Multidisciplinar e de Psicologia, Fevereiro de 2016, vol.10, n.30, p. 252-273. ISSN 1981-1179.

Recebido: 02/05/2016

Aceito: 04/05/2016 